\title{
Not-Waiting to Die Badly: Facing the Precarity of Dying Alone in Japan
}

\author{
Anne Allison
}

The presenter starts up with his PowerPoint. Five minutes in, the screen fills with things. Of personal belongings left behind after their owners have died. Stacks of newspapers; collections of model airplanes; wooden swords, slippers and books. The image shifts to another: piles of magazines and needlepoint, shelves of dried fish and rice crackers, heaps of dust cloths and mosquito coils. And yet another where the disorder is as evident as the decay: tatami mats strewn with half-eaten noodle cups, crushed beer cans, loose chopsticks and cigarette butts. ${ }^{1}$

Five or six more scenes follow this, all of matter that, once of the living, now constitute remains of the dead. But the subject of today's forum is not death as much as life: about how to live actively (ikiikito kurasu tameni) by managing the details of one's dead remains while still alive (seizenseiri). The organization holding the event is Ending Centre, a citizen's group devoted to treating death and post-mortuary practices with respect. Founded in 1989 by Inoue Haruyo, ${ }^{2}$ a leading advocate for the human rights of the dead and both professor and practitioner of what she calls midwifery - helping to birth death - Ending Centre targets those looking for alternatives to the family grave (located usually in a Buddhist temple and tied to long-time parishioner status) and the standard funeral practice (highly ceremonial and exorbitantly priced). As it says in the promotional brochure, Ending Centre helps members prepare for a good day of death (yori yoku shinu hi no tameni). The emphasis here is on both a good death and preparation, and on the individual assuming responsibility for these technologies of deathcare oneself. So Ending Centre caters to self-management of death: managing how and where one goes once dead and the possibility, sometimes choice, that this will be all alone. ${ }^{3}$ 
It is to understand more about this work that I have come to today's forum, one of two held annually by Ending Centre. The forum leader is Yagi Tomohiko, a peppy man in his early forties who is the president of Relief, a company that cleans up and disposes of belongings left behind by the deceased. Part of a new genre of Japanese business, Relief first started in 2002, with 104 staff and three offices nationwide in its fifth year of operation. Its basic service is 'katazukeru', which means to sort out, clean up and dispose. These then are 'companies that straighten up possessions of the deceased' (ihin seiri kaisha, 遺品整理会社). As Mr Yagi points out, it once was 'only natural' to expect surviving family members or close friends to sort out the remains of the dead, but this is no longer the case. Everyone is busy and living in cramped urban space, but also, thanks to the demographics of low childbirth and a high aging population, more and more Japanese are living longer, not having children, and - with the rise of an ethos of self-responsibility - not wanting to burden others with the task of managing their remains after death.

Grimacing, Yagi-san shows us the images he has brought of rooms and houses stacked to the roof with stuff. Isn't this a chore, he rhetorically asks, cleaning up the mountains of possessions left behind by the deceased? Nods of weary recognition circulate the room. At this, Mr Yagi turns on a brief video, a testimony by a man in his thirties who tells how Relief handled the clean-up of his grandmother's house. Dreading the task, the family had let the house sit as is for ten years after the woman had died. Only now, and thanks to Relief, the house had finally been emptied and the memory of the grandmother benevolently restored. Echoing the work of Kondo Marie and her method of joyfully simplifying - and reducing - the surfeit of one's material possessions, ${ }^{4}$ Mr Yagi is urging us to consider the ecology of dead remains: how, once one dies, stuff decays in rooms that no longer hold the living, becoming useless matter that does not matter to anyone else.

But why a presentation on remains of the deceased in a forum held by an organization devoted to preparing for a good death oneself? As Mr Yagi announces early on, many of the pictures come from the homes of people who died alone. This is a phenomenon, labelled lonely or solitary death (kodokushi, koritsushi), that has been much in the news of late. Typically involving someone who had lived alone for years and whose body gets discovered weeks or even months after death, this is a state - solitary living/dying - often used to indicate the trend of 'disconnected' social existence (muen shakai) in post-industrial Japan. As detailed in the television special NHK broadcast on the topic in January 2010, there were 33,000 known cases of 'lonely death' that had occurred in the country 
the year before: a number that has been rising ever since. One-fourth of the cases his company has handled involve persons who died alone, Yagi reports, adding that the men have often been hoarders, and the women collectors of everything from Tupperware to tea. Showing us multiple scenes of such residents, he said the worst he saw had garbage up to within inches of the ceiling: a real room 'stuffed with trash' (gomiyashiki). Not only dangerous to the resident while still living, such clutter is unpleasant for whomever discovers it (often neighbours or landlords who are alerted by the smell of decay). Yagi, then, is giving us a warning that concerns not (only) things left by others (a parent, aunt or spouse), but the things we would leave ourselves - and the encumbrance they would impose upon others - should we die alone. A sobering message about the future that might await us and the preparation we are to make now to ward against leaving clutter, and becoming clutter ourselves, at death.

In this chapter, I consider what such a prospect does to the social imagination: of dying alone, preparing for such a possibility, and even turning all of the above into a method for 'active living' - as invoked by Mr Yagi in his presentation on cleaning up (so as not to become one's own) dead remains. Rather than a strategy of hope per se as Hiro Miyazaki (2004), borrowing on Ernst Bloch, defines it as a method for living oriented towards a future that is not-yet, initiatives like that of Ending Centre are working towards 'birthing' end-of-life so as to contain the anxiety, and need, of depending on others when the time of death actually comes. To avoid, that is, a particular kind of future: dying all alone, unrecognized or ungrieved by others, displaced or far from home, as scholars have delineated the calculus for a bad death (Hertz 1960; Parry 1994; Agamben 1999). More than moving towards the future then, Ending Centre helps its members be freed from the future: a future of getting stuck dying badly.

The affective and practical strategies taken against this I call active not waiting', playing off what others have argued is 'active waiting' done by those attempting to survive amidst the precarity of poverty, warfare or the displacement of citizenship/home (Hage 2009; Chu 2010; Han 2011). Unlike the latter though, whose hopes and energies get pinned to a goal or world outside the here and now, 'not waiting' pitches the person more to the present, a present that gets reanimated by warding off the prospect of a bad kind of death. In both cases, attempts are being made to increase the capacity to persevere - what Spinoza labelled conatus and considered an ethical good and also 'joy' - and to avoid the 
stuckedness of immobility (Hage 2009). In the practices I look at here, however, joy comes from the endeavour made to persevere not life itself as much as the possibility (and anxiety this engenders) of dying all alone. By acknowledging and preparing for this prospect, one then lives, until death, in the here and now. This, as I see it, is the attempt to fill in what Norbert Elias has called the 'blank area on the social map' haunting death in late modern, liberal societies. As he has argued: 'Never before have people died as noiselessly and hygienically as today in these societies, and never in social conditions so much fostering solitude' (1985: 85). Dying in a state of loneliness, 'excluded from the community of the still living' (p. 66), feeling that 'he or she has scarcely any significance for other people' (p. 64). But, emerging around death these days in Japan, is the trace of something quite different: noise made around dying, even as socially single, as a possibility whose precarity is to be managed and prepared for while still alive.

Ending Centre is part of a new trend of businesses and activities (citizen's groups, non-profit organizations, commercial services) converging around the management of death in post-bubble Japan: what is generically called 'shükatsu' (the ending market - or market in death 終活). Driven by demographics - an aging population that is also dying at an historically high rate, making Japan what some call a 'mass dying society' - this is conditioned as well by economic precaritization (economic decline, a nagging recession, and insecuritization of labour and jobs that is a big factor in the high suicide rates since 1998) ${ }^{5}$ and social and residential shifts towards 'singlification. As coined by sociologist Yamada Masahiro (2014), 'singlification' (shinguru-ka) indicates demographic and residential trends towards singular living: a high aging/low birthrate society (shōshikōreika shakai) where marriage, coupling and even sex is in on the decrease, and one-third of all people, including the elderly, live alone. As singlification coordinates with economic shifts and the decline of the nuclear family, what has been the primary social unit in post-war Japan and the de facto welfare provider in lieu of the state (whose allocation of social welfare has been woefully low (Allison 2013)), Yamada sees in this the dissolution of the social, and single Japanese as socially, and existentially, bereft. 'Refugees' (kazoku nanmin) is what he calls them: the position also taken by NHK in its documentary on lonely death where the state of living, and dying, singly is treated as a sign of Japan becoming a 'muen shakai', society of disconnection.

A pitiful state, and one that is well known to the public these days, and the conjuring of its imaginary, through the constant references to lonely death in the media. And for those who die alone, where they wind up after that is common knowledge as well. If no one has claimed their remains or come forward to 
bury them in a family plot, the lonely dead are sent by the municipal office to a Buddhist temple with a gravesite for the 'disconnected souls' (muenbotoke). Here the ashes of all those with no one to bury or memorialize them are collected and comingled: as unmarked and promiscuous in death. Muenbotoke means disconnected, and also abandoned: a meaning that an acquaintance instructed me on when we went to visit the grave of a recently deceased friend. Passing the burial site for the muenbaka (the grave for the disconnected) in the Buddhist cemetery, she noted its untidiness. With weeds overgrown and no flowers or incense left as offerings, it lacked the touch of care: the tending a child or kin should provide, making and marking the deceased as 'grievable. As defined by Judith Butler, grievability depends on 'a social network of hands.' 'Only under conditions in which the loss would matter does the value of life appear. Thus, grievability is a presupposition for the life that matters' (2010:14). Without those hands, making them matter to somebody else, the dead become abandoned: a state that is both lonely and unseemly, as my friend implied with a frown. Dead matter that does not matter to the living: socially void, the sign of a bad death.

But not everyone is so dystopic about the trending of singlification as an increasing lifestyle and deathstyle in post-industrial Japan. Feminist and sociologist Ueno Chizuko, for example, has written two bestselling books about living as an 'ohitori-san', a single person, and, more recently, Ohitorisama no saigo (2015), something of a guidebook on how to manage end-of-life including dying at home: what she calls not lonely or solitary death but single death at home (zaitaku hitori shi). And Inoue Haruyo, the founder and director of Ending Centre, finds a growing response to initiatives such as her own to help people manage mortuary and post-mortem arrangements outside the convention of the family grave and, sometimes, without the involvement of kin altogether: what she has coined 'detachment from the succession system' (datsukeishō). Notably, the individual is called to handle what once was the duty of others: something these new endeavours enhance by appealing to the consumerist desire of choice - one can now die jibunrashi, as one likes. Couched in the language of freedom, how one dies becomes a matter of self-care, the technologies and cost of which depend on the inclination and resources of the individual (acting as liberal subject, liberated from traditional custom). But such a mindset, of preparing and assuming responsibility for one's own mortuary arrangements, is not merely the purview of the well-healed and moneyed (or childless and single). Aging day-labourers in the San'ya district of Tokyo, for example, have established a collective haka (grave) to be buried in when they die. ${ }^{6}$ Rather than be alone and abandoned, they join each other when dead: a concept not unlike that of 
Ending Centre where one makes 'grave-friends' to be buried next to so as not to be lonely post-death.

This is the terrain I explore here: how the prospect, or possibility, of dying alone is changing the ecology between the living and dead in the postindustrial landscape of twenty-first-century Japan. In what are times marked by precarity - the irregularization of the job market, the nuclear dangers posed by the meltdowns at the Fukushima Dai-ichi plant, the demographic shrinking and aging of the population - the sociology of relatedness is transforming. What had once been the norm in the way of durable relations over time (of marriage, work, locale) is becoming far more uncertain today. But, as Anna Tsing has noted about precarity, what she calls the 'condition of our time', uncertainty itself can prompt new forms of life, death and life out of death. 'A precarious world is a world without teleology. Indeterminacy, the unplanned nature of time, is frightening, but thinking through precarity makes it evident that indeterminacy also makes life possible' (2015: 20). What, then, is the kind of life, and for whom and under what conditions, getting animated by the possibility of dying alone in Japan these days? And what are we to make of the efforts, and now businesses, that embrace a policy of not waiting to deal with the sociological indeterminacy of dying alone? My argument is that, while singlization is an increasing fact of life in Japan, it spells less the end of the social per se as much as the emergence of new ways of constituting and imagining being with/out others - new assemblages and assemblies of life, non-life, and a border that is shifting between the two.

\section{The placement/displacement of the dead}

What older Japanese fear the most is abandonment, according to Jason Danely (2013), an anthropologist who has studied aging and dying in contemporary Japan. Even more than death itself or the physical deterioration of one's body and health, the thought of being all alone, discarded or forgotten by others, is disturbing. And all too possible, as we have seen. Even for those living in the countryside, the bastion of 'village society' where ties with neighbours, workmates and kin might be thought to be strong, the suicide rate of the elderly is high, even higher than in the cities (Traphagan 2004). The elderly often feel isolated, Danely discovered, and even amongst family the generation gap with children and grandchildren can be vast. Meanwhile friends are dying or moving away, further shrinking the world within which one feels at home. Losing a sense of connection and recognition, elderly people struggle with the desire to not be a 
bother as well. As Danely heard time and time again, a premium value is placed on not being a burden to those one would (otherwise) most likely depend upon: family and kin. Such a moral principle has only intensified in the neoliberal environment of post-1990s Japan when, after the bursting of the bubble economy and the onset of a nagging recession that has lasted twenty-five years, an ethos of 'self-responsibilization' has been heralded from the government on down (Allison 2013).

And yet, 'bother', as in expending energy and care on/from another, is precisely the relationship the living are expected to maintain with the dying and the dead. Conceptualized as a social contract, the relationship is to be one of inter-generational dependence and reciprocity. Based in the family, family members are to care-give for the elderly and ritually tend to the dead by nourishing them with offerings and food. The latter, as noted by anthropologist John Traphagan (2004), constitutes a practice that itself is constitutive of what stands for religion in a country where most Japanese consider themselves not actually religious. Calling this - and cognate rituals that tend to spirits, ancestors, gods, others and oneself - a 'practice of concern' (the title of his book on the subject), Traphagan considers it a 'pedagogy of agency' driven less by theological interest than a sense of morality to dead others but also for others in maintaining one's own well-being and health. What this comes down to in terms of practising concern for the dead is giving offerings, memorial and food on both an everyday basis (at the butsudan, or Buddhist altar kept in the home) and seasonally (during O-bon, the season for receiving the dead back home, as well as on designated anniversaries of death). Fittingly then, the spectre of disconnected souls (muenbotoke) is that of hungry ghosts, who receiving 'no veneration are fated to become pitiable homeless spirits, bereft of the taken-forgranted human and posthumous conditions of connections and reciprocity in Japanese society' (Kawano 2010: 11).

The homelessness of the dead is a sign of post-industrial times. Of shifting conditions that make precarious, or impractical, the social contract once held between the living and dead. As was the norm in post-war Japan, this contract devolves upon the family: venerating the dead at the domestic altar (usually Buddhist, but sometimes Shinto) and at the family grave where generations of the family's remains are interred. Genealogically sacred but also guided by a principle of primogeniture granting only the eldest son the right to be buried there, the family grave marks the emplacement of ancestors and also the contact zone between the living and dead. As such, it serves as 'receptacle for the spirits of the ancestors, a site for ritual offerings to the dead, and a symbol of family 
continuity and belonging' (Reader 1991: 96). Bred here is a relationship of reciprocity; the dead look over the living and the living help ease the passage of the spirit to the other side. While practices and beliefs vary, they often combine a mix of popular beliefs (including ancestor worship) with Mahayana Buddhism in which the spirits of the dead, referred to as 'buddhas' (hotoke), depend upon the living to perform rituals of memorialization. Under these beliefs, the dead are thought to become honoured ancestors, buddhas (or gods, when Shinto rituals are added in), with the assistance of living descendants (or bodhisattvas) who perform memorialization.

To not perform these mortuary rituals has long been thought to incur danger to not only the dead (at risk of getting stranded or lost), but also the living (on whom an angry spirit can wreak damage and harm). Particularly vulnerable or volatile in the early period following death, spirits require purification and consolation (Suzuki 2000). Buddhist priests chant sutras and the body is washed and dressed before cremation. Then, on the 49th day and when given a Buddhist posthumous name (kaimyo), the deceased becomes a buddha (hotoke). To safely make one's passage from this world to the next, the hotoke still relies on help from the living, which includes the money spent on mortuary arrangements (the more spent, the quicker the passage, it is said) and offerings made through services $(k u y \bar{o})$ for the spirit at the memorial tablet (ihai) kept at the household altar as well as the grave. But eventually the hotoke will merge with the collective body of ancestors and/or deities (often considered to take between 32 and 33 years) at which point the individual's ihai can be discarded or moved back in the household altar and family grave (Reader 1991; Kawano 2010).

In the urban migration that followed the end of the war, in the 1950s and 1960s, Japanese flooded to the cities, leaving a lifestyle of 'village society' marked by extended households and ancestral attachments behind. Tending to the dead has become far less convenient now, and less part of the everyday rhythms and landscape of the living. With the family grave far away, Japanese have to make long treks back to natal homes for O-bon, the season of inviting the dead back for a short visit. Residences in the cities are often smaller than in the countryside (with little room for a Buddhist altar), and lifestyles busier (making daily or seasonal memorial more difficult). And the household has narrowed; the residential pattern for families has shifted from the extended to the nuclear and Japanese are increasingly living alone, remaining unmarried, and not having children. This impacts on how many still have a family grave, for to maintain one at a Buddhist temple requires that the family be long-standing parishioners: an investment in commitment and considerable funds over 
the years. Without such ties that need to be cultivated and nursed over time, many find the money owed a temple or priest on the occasion of death to be unseemly: a gross extraction of cash rather than the gift of memorial meant for the dead. The price tag on funerals, as well as gravestones and memorial goods (including kaimyo, which can be shockingly expensive), is high and difficult for those struggling in the uncertainty of the current labour and financial market. Today, more and more Japanese opt for streamlined versions: the 'direct funeral' or 'family funeral' at the graveside that forego the elaboration of a more formal affair where attendants are treated to a meal, drink, and gifts.

What does it mean for the constitution and temporality of society when memorializing the dead begins to fade as a genealogical proposition? Continuity, as scholars like Emile Durkheim have long noted, is the marker of the sacred, and itself, of the social: marking life as extending beyond the physicality of the biological body, the entity of the individual and the temporality of the here and now. Giving respect to the dead is universal, Thomas Laqueur argues in his recent book, The Work of the Dead: 'We live with the dead for they define generations' and 'demarcate the sacred and the profane' (2015: 4). But what Laqueur calls a universal regard for the dead is, in fact, premised on a very particular notion of the social: what a number of sociologists (for example, Berger 1969; Aries 1981; Elias 1985; Giddens 1991; Lasch 1991) have found to be shrinking in post-industrial societies along with the privatization and individualization of everyday life. As they have argued, whereas it was once an imminently social affair surrounded by ritual, religion and the acts of grieving others, in the biopolitics given life today, death gets medicalized and the dead hidden away in hospitals where individuals die alone and detached. In societies oriented to the future (the hallmark of modernity), there is little space or accommodation for death: which makes those facing it feel so vulnerable and scared. Dying thus becomes a lonely endeavour, as Elias has noted, not only socially but also existentially when the structures for making sense of it are no longer in place (Mellor and Schilling 1993).

Yet, agreeing with Charles Hirschkind (2008), who finds death less invisibilized in the post-industrial global north as the object of distinct sets of knowledge and practice where it features quite centrally in ethical and political life (around the issue of abortion, for example, in the United States), I see recent changes in Japanese end-of-life and mortuary practices to indicate not the death of death per se but more a shift in how it shapes, and is shaped by, the social - which itself is shifting at the same time. Less dependent on the family (for care) and less tethered to a principle of continuity (for marking the dead), emerging is a new ethics and sociology around the self-management of death - which is what I turn to next. 


\section{Preparation to die otherwise}

It is June 2015 and I have come to a workshop on care held by the Tokyo People's Action Volunteer Centre. The central headquarters for volunteering in Japan, it is hosting the event for a non-profit organization (NPO) called Association for Making Connections in Housing and Living for Old Age. The main topic for discussion is care, and things start off with a presentation by a woman who runs her own NPO, Aladdin, geared to supporting networks for caregivers. Addressing a room of about 45 people, mainly middle - to older aged, Ms Makino says she is delighted to see so many men. This is the first time women have not dominated her audiences and she wonders if this is a new trend. Beaming widely, she energetically starts in.

Support activities (shien katsudō) geared up in Japan at the time of the Hanshin Earthquake in Kobe in 1995. Before then, care had been primarily the purview of the family, she tells us. But, with the crisis of the earthquake that included numbers of people who died all alone - which ignited awareness of the problem of 'lonely death' and also measures taken by community and municipal groups to address it - this started to change. Today, more and more public, civic and community initiatives have emerged that are extra-familial organizations: helping to supplement or substitute for a caregiving that once devolved upon the family alone. Ms Makino refers to such care provider networks as 'para-families' (giji kazoku), noting shifts in the demographics of caregiving. While once it was overwhelmingly women, as daughters and wives, today 30 per cent of caregivers are men. And while 55 per cent of those taking care of the elderly are over the age of 60, increasingly the trends in delayed marriage, delayed or no childbirth, and singlification (one-third of adult men and one-fourth of adult women stay single) mean that it is not only, or necessarily, family members doing the caring, which is also taking place increasingly at home (zaitaku). Yet sadly, Ms Makino tells us, shaking her head, that only 35 per cent of Japanese are prepared for this process according to a 2012 survey done by Asahi Seimei on family and care. The woman in her sixties sitting next to me leans over to say this is exactly her situation; she came today from two hours away to start preparing for the next stage ahead.

The rest of the presentation focuses on various facilities or initiatives that offer support to caregivers (or 'carers', keara- $z u$ as she calls them): community cafes, chatrooms, monthly get-togethers over coffee or beer. Offering a much-needed break in one's routine and an opportunity to mingle and learn from others in a similar situation, these are a social safety zone: a people's assembly - using the 
term Butler lays out in her recent book (Notes Towards a Performative Theory of Assembly, 2015). As she defines it there, an assembly is driven by a shared sense of not only precarity (as in insecurity stemming from insufficient resources) but also responsibility (as in the responsibility caregivers assume in caretaking someone else but also caring for themselves). 'The more one complies with the demand of "responsibility" to become self-reliant, the more socially isolated one becomes and the more precarious one feels' (2015: 15). Indeed, isolation is one of the biggest sources of strain that caregivers experience, as Ms Makino explains. But coming to a carer's café opens up both a space and time to be responsible/ precarious together: what Ms Makino calls an 'ibasho', a place where one feels comfortable and at home. ${ }^{7}$ Sharing with us letters from carers who have attended these cafes, she reads one by a man in his thirties who has been caring for his 100-year-old grandmother still living at home.

It is hard taking care of someone, and I have been all alone with no one to share this with. I am so thankful for this café. Having it means a relief for my heart that has been sequestered in an evacuation shelter.

Although Ms Makino notes the risk of isolation and solitude more generally in Japan today, at a moment when more and more Japanese are living alone and trending away from couplings (including sexually; as much as 40 per cent of Japanese youth report being unengaged sexually and sexlessness is high even among the married), ${ }^{8}$ she fails to mention the proliferation of alternative forms of communication and companionship that have arisen alongside these social shifts. The market is booming these days in everything from social media and chatrooms, virtual relationality (with characters, idols, video games) and paidfor company or romance (rental families and friends, host and cabaret clubs) to dolls (ball-jointed dolls customizable by taste), robots (such as Sony's Aibo) and pets (hugely popular, with a wide array of services being provided for them, such as cat cafes, dog yoga studios and pet cemeteries). How intimacy formed with a character or dog, or affectivity formed with a paid-for caregiver or host, differs from that of a relationship forged through marriage, family or friendship is a complex and variable matter. But the fact that memorial services (kuyō) occur today for not only pets but also Aibo robots, tamagotchi, dolls and cellphones ${ }^{9}$ reflects the degree of affection and attachment owners feel for such companions and the interpenetration of such virtual/pet/technological companionship in the social and intimate lives of twenty-first-century Japanese. In the domain of care, much research is being done on the development of technological caregiving; Japan's R \& D in care robotics is the most advanced in the world, 
driven by the country's highly aging society and what is already a care deficit (in provisions and providers of care). Thus, while not addressed in the forum today, it is important to keep in mind how such social shifts as singlification and self-care (managing the self, by the self) in Japan today are both enabled by and generating themselves, commercial/non-human apparati for attending to such basic 'human' needs as communication, companionship and care.

After speaking for an hour, Ms Makino ends her presentation. Following a short break, we are invited back into the room for break-out sessions around the issue of different residential arrangements for senior living - whether at home or a facility, and whether all alone or with a partner or family. Having designated my own likely course to be at home with a partner, I am put in a group (the smallest in the room) with three others, all married men. Facilitated by a member of the NPO running today's workshop, the discussion revolves around the dynamics of care and how we all are doing, what stage we are at, and what issues we are having now or anticipate in our future. One man, aged 78 , says he is in the throes of caregiving (kaigoch $\bar{u})$; his wife has been sick and although they have an adult child who lives at home with them, they do not want to burden her with the chore. So he has been doing the bulk of it, all the while trying to maintain his own health to alleviate the need for a caregiver himself for as long as possible. Another man, aged $72,{ }^{10}$ has a wife and two adult children at home, and while both he and his wife are still fit, he is here today to start planning ahead. The third man, aged 50 , is concerned about re-establishing contact with his estranged children from a first marriage but, as an end-of-life counsellor himself, it seems he is here in large part to drum up clients. And when my turns comes, I tell them about what was uppermost in my mind at the time: dealing with an aging mother who had recently developed Alzheimer's.

Our facilitator is engaging and warm in facilitating discussion and offering advice about the aging process. And throughout, as she concludes at the end of our hour with her, is the message: take care of yourselves and prepare for endof-life as soon as you can. The feel is both upbeat and moralizing - about how to just jump in and face aging/death with a light heart but also how essential it is to manage this as earnestly and quickly as one can. I get up to leave, at once energized and exhausted by the task: the task of caring, as in looking after oneself (in looking after others) but also of caring for oneself by biopolitically technologizing the self in preparation for dying. This seems a somewhat different threshold of life/death from what Foucault (2003) outlined in his concept of biopolitics. For, as he argued, in the transformation from sovereign power organized around the right to take life or let live to a different technology 
of power targeted to the living instead (as in making the species stronger, more productive, less diseased or short-lived), death now becomes hidden away as something private, even shameful. Power no longer recognizes death; it literally ignores it, Foucault has written of the biopolitical age. But this is not what I am seeing this day in the Tokyo Volunteer Centre. Rather, death here is centrestage, as it is in the proliferation of initiatives, services and businesses that now help people manage it well (shükatsu). In preparing for a good death, one is being asked/tasked/serviced to adopt self-responsibility towards oneself. A preparation that is a practice, something akin even to a ritual, in that organizing for death is also intended to be a method for living life (more fully) until the end. So, animating death in order to animate living before death; less a matter of biopolitics, this may reflect a new order of power around the management of life/non-life (abetted by robots, pets, virtual companions and caregivers). Not necropolitics in Mbembe's sense (2003), but something perhaps akin to what Povinelli (2016) calls geontopower, referencing the break-down of the old binarisms between life and death, life and non-life in late liberal societies.

On the way out, I grab some materials laid out on the table. One of these is a citizens' newsletter printed by the city of Yokohama. The main article is a synopsis of a forum recently led by the founder and president of Keepers, the first company specializing in the clean-up of the remains of the deceased (ihin seiri kaisha). Started in 2002, the company now handles 1,500-2,600 cases a year, 200-300 of which are of people who die alone. The majority (70-80 per cent) are men (true as well for the phenomena of social withdrawal and suicide - usually correlated with the normative centrality of work in the lives, identities and social companionship of men; lonely diers are typically men who lose connection to the outside world after retiring or losing jobs) and, if they die with bodies that remain undiscovered for longer than a week, the smell can be horrific, as $\mathrm{Mr}$ Yoshida graphically described to the audience. This leads into the first of his two main points:

We can't let this occur - these deaths of people who die alone recognized by nobody [kizuite moraenai shi] surrounded by what becomes the possessions of the deceased. In order to prevent this, it is important for us to be people who won't be discovered in these conditions (A-tofuo-ramu Azamino, 28 February 2015: 3).

If the first point is about death - about not being cluttered with stuff that will only inconvenience others if one should die 'unrecognized' at the end - the second is about life - about 'leading a full life everyday', as he put it, and devoting most of one's resources on the time that is remaining. What is important, Yoshida 
urged in his talk, is 'quickly coming up with a concrete plan' for how to use, and use up, one's money in the here and now. Keeping one-third of one's resources in reserve (for emergencies or if one lives longer than expected) is recommended, but, after that, one should spend on the present: enjoying a 'full time' with others or by oneself.

On both scores then, what is advised is active not waiting: to be active in the present by spending one's later years not passively awaiting and feeling anxious about (a bad) death. But there is a message here too about the kind of death one should engineer: a remainderless death, leaving no remainder (as in the clutter of personal possessions or even money or property) that someone else (children or relatives) would inherit once one dies. ${ }^{11}$ Although not using the word 'muen' (without connection), Yoshida envisions here a remapping of the strands of sociality and temporality that once organized the matters of life and death in 'village society' Japan. Oriented less towards ancestors in the past or descendants in the future, the focus is more on being present in the now and making a form of connectedness here. The threshold death, once represented as a gateway to joining ancestors but with the precarity of having to make one's way through to the other side, is thus reconfigured. Attention is paid instead to managing the anxiety of imagining dying all alone: a precarity felt more in the present and thus relieved (anshin suru) by attending to the preparations for one's death as soon as possible.

This is the lesson taken by one of the participants in the forum at Yokohama. In her reflections on Yoshida's presentation in the newsletter, she writes of cleaning up her house recently and noticing how much she did not really need. Things that had value to her would be 'unneeded things' once she died, becoming the remains of the deceased (ihin). Admitting that she could imagine becoming part of the social phenomenon of dying alone - 'one never knows who or when someone will die a lonely death; it could happen in the middle of a normal life' - she says the most memorable thing she learned from Mr Yoshida was to 'decide what you want to do until what age you want to do it' and spend twothirds of your resources on that. This was a positive message, stressing decisions made by oneself for oneself, about the things one wanted to do (yaritai koto). And, as long as one acted according to what one had decided in life, then it did not matter if one lacked 'connections with others to manage, and straighten up, one's stuff at the end. One could have a 'bright feeling' (akarui kimochi) anyway (A-tofuo-ramu Azamino, 28 February 2015: 3). Embracing a Spinozan principle of joy, the emphasis here is on increasing one's capacity to persevere in the now despite the uncertainty of how one will die in the future. 
All of what I learned at the workshop this day involved methods for actively coping with caregiving for others and caregiving for oneself, in an age of singular living and dying alone; and about trying to do this responsibly in the face of a precarious, or limited, 'social network of hands'. But what of preparations made for after-death as well? Is there any attempt to retain something sacred here: ways of marking, or attending, the deceased other than through the genealogical principle of belonging dictated by vertical ties of membership and obligation? A different sociality of/for the dead? This is the issue I address in the next section.

\section{The sacred by other means}

This is a moment of great innovation around mortuary and post-mortem practices in Japan. Given the high percentage of elderly in the population (26 per cent over the age of 65, which is projected to rise to 38 per cent by 2055), and the trend towards singlification, more and more Japanese are living alone, and ever more finding themselves homeless or unsure of their dwelling once dead. This is the state of muenbotoke, as we have seen: souls displaced from a line of continuity with the yet unborn and dead ancestors of generations past. The latter is the domain of the sacred, whether it is constituted along religious grounds or more secular grounds as Benedict Anderson has argued for nationalism in Imagined Communities (2006). For what religions provide is a way of conceptualizing endof-life as continuous with life in different terms: reincarnation, heaven, paradise, nation-state.

In modern Japan, grievability has been the purview of the family; one grieves, and is grieved by, others who are linked by marriage or blood. The site around which this converges is the family grave. Yet this was never always already a happy story: one necessarily of inclusion in which everyone, by fact of kinship, gains entry into the ranks of the grievable dead. As described by Inoue Haruyo (2012), the founder of Ending Centre, when her mother died at age 62 in 1981, there was no family grave for her to be buried in. Married to a second son who, under the rule of primogeniture, had no rights to burial in his family grave, their own nuclear family was without one. So the family had to start building one at the very time when the family was mourning the mother's unexpected death: a traumatic memory for Inoue. A friend shared a similar story of her father who died unexpectedly in his sixties. Also a second son without a family grave, the family buried him in a temporary burial plot for a year while constructing their own family grave - at much expense and great inconvenience. Another 
friend, a woman who is married but childless, is worried about who will perform memorial rights when she and her husband die, and also where they will be buried (as her husband's family has no grave and, having a different married name, she is not allowed into the grave of her father's family). She also worries about her aging mother living all alone far away. Although she would like to bring her to live with them, this would leave the soul of her dead father without someone to perform memorial $(k u y \bar{o})$ for him at the family grave

As these stories show, even those with 'family' are often stranded or stressed about their placement in a family grave upon death. This is due, in part, to the nature of Japan's succession system (keishō seido) that, besides upholding the principle of primogeniture, also demands that women change their maiden name upon marriage (by law in a ruling the Supreme Court upheld in 2015). Retaining elements of the old family system (when patriarchy and religion converged around the emperor as the nation's father and god) despite the changes applied to it under the post-war democratic constitution, the system maps out succession on an exclusionary basis. Women, for example, can enter the natal grave as daughters but lose this connection once married. As Inoue has noted, they become 'disconnected' (muen) from their family of birth upon marriage (2012: 14). But should a woman then get divorced, keeping her married name but losing the right to be buried in a husband's family grave, she is doubly displaced. The lines of succession cut many people out: single or childless households, couples with only daughters, second or third sons, divorced women and women in general. And coupled with the exigencies of modern, urban lifestyles when people move more often and far away from parents or offspring, the alignment of succession and grievability are increasingly at odds.

It is for this reason that Ogawa Eiji, the head priest of Myōkōji Temple (Nichiren sect of Buddhism) in Niigata, wrote what in 1989 was a controversial article in a weekly news journal, 'How to Avoid Dying Without a Grave'. Advocating the disaggregation of the burial system from the family and family grave, he initiated a new way of being buried and memorialized outside family attachments the same year. This was in a communal grave, with the guarantee of memorial rites to be carried out by someone at the temple (for thirty-three years), and at a reasonable cost that does not require becoming a parishioner at the temple. This system, called eitaikuyō (eternal memorial), has now spread to many temples across the country. By offering it, or something similar, to a consumer base that is responding increasingly well, revenues have been generated to help sustain what had been (and still is) a declining religion. This new business of death has given life to many Buddhist temples, and priests across the country, as Ogawa 
admits. And today people are constantly coming to Myōkōji to seek out advice, as he told me in an interview: both individuals struggling with the issue of 'Where to go when I die?' and Buddhist practitioners keen for the know-how on how to refortify by diversifying their religious practice.

An early collaborator with Ogawa, with whom she ran a seminar in the 1990s to discuss the relationality around graves in twenty-first-century Japan, Inoue started Ending Centre around the same time and is well known today for her end-of-life work and human rights advocacy for the dead. Conceived as a citizen's group for treating death and post-mortuary practices with respect, Ending Centre has evolved since 1989 into a registered NPO with burial grounds of its own. Seeing its mission as midwifery, helping to birth death, Inoue is nonreligious in orientation and interested less in securing grievers for the to-bedeceased and more in producing a sense of security in and at death. Located on the outskirts of Tokyo, within a beautiful Buddhist cemetery with which it has no religious affiliation, Ending Centre is strewn with cherry trees, making nature one of the major attractions of those who choose to be buried here. The other, Inoue told me the day I visited, is a mortuary practice non-dependent on the succession system. Here the dead commune with nature in a burial ground where this and other alternative forms of companionship (such as pets, which are allowed to be buried with humans) take the place of or need for family. The dead are never alone here, its brochure points out, connected as they are to a braid of relations as with falling cherry blossoms. Rather than muen (disconnected), Inoue calls such a state - of being dead with, if nothing or no one else, cherry blossoms - ketsuen: which I translate as differential relatedness.

Returning to Judith Butler and her notion of the assembly that responds to precarity in a manner that engages 'embodied action and forms of expressive freedom' (2015: 10), I apply it to such initiatives as Ending Centre which, addressing the possibility of dying alone, are coming up with practices for facing this with both creativity and respect. Here the effort is made to actively not wait for death but to embrace the end, and the time one has before getting there, with something akin to joy and life. One strategy is preparing for a remainderless death by leaving no clutter behind, including the need to be grieved or memorialized by someone else.

As Inoue articulated it, the system at Ending Centre is one of individual 'freedom', choosing oneself, for oneself, how to be buried and (un)mourned which could be considered the height of a neoliberal logic, taken quite literally to death. But what I sense is driving this, at least in part, is the very real fear of being abandoned at the end, and the desire to manage, and be in control 
of, this while one can. And such an affective complex pertains not only to the mainly middle-class clientele I encountered in such NPOs as Ending Centre and the one running the workshop I attended at the Tokyo Volunteer Centre, but also to the aging day labourers in San'ya and Kamagaseki in Osaka, ${ }^{12}$ whose motivation behind the collective graves they have built is to relieve the pain of anticipating being all alone/stranded when dead. The word I continually hear in these contexts is 'anshin', peace of mind, a sense of relief: what Ending Centre promises as part of its plan and what a staff member for Sanyūkai in San'ya also called the effect/affect of the collective grave now existing in San'ya. Avoiding a future of being abandoned at death, one reassembles the lines of relationality both in life and for death. Stitching together a different kind and assortment of ties, including non-human with cherry blossoms and pets, this is not based on a continuity of lineage across time, the transmission of property or ties of obligation, or the structure of membership by nationality or blood. Rather, it comes from something else. From a refusal perhaps to have a bad death. For, as Butler says, speaking here of a bad life instead of death:

if this sort of world, what we might be compelled to call 'the bad life', fails to reflect back my value as a living being, then I must become critical of those categories and structures that produce that form of effacement and inequality. In other words, I cannot affirm my own life without critically evaluating those structures that differentially value life itself (2015: 199).

One of the methods Inoue has designed for coping with all aloneness at the end of life, and beyond death, is that of a 'grave friend' (haka tomo). This entails making friends with someone to be buried next to at the time of death: a new friend with whom one buys adjacent plots in a burial ground and also starts associating with before one actually dies. ${ }^{13} \mathrm{~A}$ friend for the future to avoid solitariness once dead. The relationship that ensues is not one of mutual grievability or assistance in passing into the other world, helped by a friend instead of kin. Less instrumental or structured than this, it is simply accompaniment into death: an assembly based on precarity as much as responsibility now of the dead. This is a different conception of the sacred, bearing the seeds of a social differentially aligned in relatedness as well as time. One in which being single does not necessarily condemn one to the socially excluded; muenbotoke. And one in which co-residing, as dead, is something in and of itself: a means of dying actively and not-waiting to be homeless or lonely post-death. 
Rather than signalling the end of the social, I see in this and the other initiatives dealt with in this chapter the emergence of new forms, and styles, of relatedness, organized around the crucible of death. Necro-sociality, we can call this. But, worked out over death, its implications also bear on the living: on how the calculus and constitution of existence are getting rejuggled vis-à-vis others and on how the distinction between life and death, and between life and non-life is shifting ground. As the director of another NPO, whose mission is to help single women deal with aging and death together, has said of the collective grave it has erected: 'A grave is not only a place for the dead; it is also a gathering place for the living. ${ }^{14}$ Not sequestered away, the dead here enjoin the living to gather together - with them and one another - in a space as much of assembly and life, as of grievability and death. In this realignment of the ecology between life and death may be the germs of a new grammar for assigning (social/sacred) meaning to both.

\section{Notes}

1 I thank Manpreet K. Janeja and Andreas Bandak for the invitation to contribute to this volume and for their excellent suggestions and feedback on my essay.

2 Japanese names are written last name first, in Japanese style.

3 From the four meetings I have attended, members seem primarily middle class, slightly more women, and overwhelmingly middle - to late aged.

4 A self-proclaimed 'organizing consultant', Kondo Marie has written several bestselling books, and the 'KonMari Method' has now become hugely popular overseas, including in the US.

5 The suicide rate has been declining since 2011 but still remains high, particularly for men in their thirties and fifties, and the elderly.

6 Conceived by the NPO (non-profit organization) Sanyūkai, which raised the funds and built the grave, it is non-denominational, although a Buddhist priest officiates at all burials and memorials. Sociologist Matthew Marr (n.d.) has been writing about and working with Sanyūkai; I thank him for introducing me to its grave project.

7 This is a word I heard repeatedly in the course of doing fieldwork on precarity in Japan between 2008 and 2011. Mainly I would hear Japanese say they lacked ibasho (ibasho ga nai) - a space where they felt comfortable and at home. There was a sense of affective or existential homelessness even for those not physically homeless. I also encountered many attempts to create new ibasho, as in a café run by and for hikikomori (socially withdrawn youth) in Niigata and in a 'regional living room' - a converted home where anyone could drop in for the day and share tea, lunch and the company of others - also in Niigata (see Allison 2013). 
8 Sociologist Masahiro Yamada reports that Japanese married couples have the lowest sex rate amongst all industrialized countries. Also, according to his own research, and surveys done by NHK, the rate of young people who report disliking sex is steadily going up, while the rate of junior high students reporting having a crush on someone is steadily going down (presentation at the Kadokawa Summer Programme, 12 July 2016).

9 NHK reported on a kuyō service held in a Buddhist temple in Chiba for Aibo robots, in summer 2015. In doing research on tamagotchi in the late 1990s, I discovered websites where owners posted requiem to their 'dead' pets (Allison 2006). Offering $k u y \bar{o}$ for pets is a service many pet cemeteries now offer, as in offering kuyō for treasured belongings (futon, dolls, cellphones, computers) - a service that many companies handling the clean-up of the belongings of the deceased now offer free of charge (see Yoshida 2011 for an interesting description of the rationale behind this).

10 Both these men seemed to be retired white - collar workers.

11 As he has written elsewhere (Yoshida 2015: 22-26), the value of property that would be left as inheritance has become precarious itself in recent years; 18 per cent of all houses in Japan are currently 'empty' (akiya) (predicted to rise to 30 per cent by 2030), most if not all in the countryside having been abandoned when owners migrated to the cities. Finding upkeep and location undesirable, which may be true too of vacation homes acquired in ski resorts or the seaside, descendants are increasingly renouncing their inheritance (sōzokuhaiki) in anticipation that it will be more of a deficit than an asset.

12 Similar to the collective grave at San'ya, one has also been built in the Kamagaseki neighbourhood in Osaka for aging day labourers there.

13 Ending Centre has recently acquired an empty house and converted it into a meeting place it calls Mō hitotsu wagaya - One More Home. Members who have acquired plots in Ending Centre and call one another 'haka tomo' (grave friends) assemble here for various activities include lunch and making crafts.

14 Matsubara Junko, director of Single Smile Senior Life (SSS).

\section{References}

Agamben, Giorgio. 1999. Remnants of Auschwitz: The Witness and the Archive lated by Heller-Roazen. New York: Zone Books.

Allison, Anne. 2006. Millennial Monsters: Japanese Toys and the Global Imagination.

Berkeley: University of California Press.

Allison, Anne. 2013. Precarious Japan. Durham, NC: Duke University Press.

Anderson, Benedict. 2006 / 1983. Imagined Communities. London \& New York: Verso. Aries, Philip. 1981. The Hour of Our Death. London: Penguin. 
A-tofuo-ramu Azamino (At Forum Azamino). 28 February 2015. Yokohama shibu kōza repo - to (City of Yokohama Chair's Report).

Berger, Peter. 1969. A Rumour of Angels: Modern Society and the Rediscovery of the Supernatural. New York: Doubleday.

Butler, Judith. 2010. Frames of War: When is Life Grievable? London: Verso.

Butler, Judith. 2015. Notes Toward a Performative Theory of Assembly. Cambridge, MA, and London: Harvard University Press.

Chu, Julie. 2010. Cosmologies of Credit: Transnational Mobility and the Politics of Destination. Durham, NC: Duke University Press.

Danely, Jason. 2014. Aging and Loss: Mourning and Maturity in Contemporary Japan. New Brunswick, NJ, and London: Rutgers University Press.

Elias, Norbert. 1985. The Loneliness of the Dying lated by Edmund Jephcott. Oxford: Basil Blackwell.

Foucault, Michel. 2003. 'Society Must Be Defended': Lectures at the College de France, 1975-6 lated by David Macey. Edited by Mauro Bertaini and Alessandro Fontana. New York: Picador.

Giddens, Anthony. 1991. Modernity and Self-Identity. Cambridge: Polity.

Hage, Ghassan. 2009. 'Waiting Out the Crisis: On Stuckedness and Governmentality'. In Waiting, edited by Ghassan Hage, 97-106. Carlton: Melbourne University Press.

Han, Clara. 2011. 'Symptoms of Another Life: Time, Possibility, and Domestic Relations in Chile's Credit Economy'. Cultural Anthropology 26(1): 7-32.

Hertz, Robert. 1960. Death and the Right Hand. Glencoe, IL: The Free Press.

Hirschkind, Charles. 2008. 'Cultures of Death: Media, Religion, Bioethics'. Social Text 26(3): 39-58.

Inoue, Haruyo. 2012. Sakurasō: Sakura no shita de nemuritai (Cherry Blossom Funerals: I Want To Sleep Under a Cherry Tree). Tokyo: Sanseido.

Kawano, Satsuki. 2010. Nature's Embrace: Japan's Aging Urbanites and New Death Rites. Honolulu: University of Hawaii Press.

Laqueur, Thomas W. 2015. The Work of the Dead: A Cultural History of Mortal Remains. Princeton, NJ, and Oxford: Princeton University Press.

Lasch, Christopher. 1991. The Culture of Narcissism. New York: Norton \& Co.

Mbembe, Achille. 2003. 'Necropolitics'. Public Culture 15(1): 11-40.

Mellor, Philip and Chris Schilling. 1993. 'Modernity, Self-Identity, and Sequestration of Death. Sociology 27(3), 411-431.

Miyazaki, Hirokazu. 2004. The Method of Hope: Philosophy, Anthropology, and Fijian Knowledge. Stanford, CA: Stanford University Press.

Parry, Jonathan. 1994. Death in Banares. Cambridge: Cambridge University Press.

Povinelli, Elizabeth E. 2016. Geontologies: A Requiem to Late Liberalism. Durham, NC:

Duke University Press.

Reader, Ian. 1991. Religion in Contemporary Japan. Honolulu: University of Hawai'i Press. 
Suzuki, Hikaru. 2000. The Price of Death: The Funeral Industry in Contemporary Japan. Stanford, CA: Stanford University Press.

Traphagan, John W. 2004. The Practice of Concern: Ritual, Well-Being, and Aging in Rural Japan. Durham, NC: Carolina Academic Press.

Tsing, Anna Lowerhaupt. 2015. The Mushroom at the End of the World: On the Possibility of Life in Capitalist Ruins. Princeton, NJ, and Oxford: Princeton University Press.

Ueno, Chizuko. 2015. Ohitorisama no saigo (End of Life for the Single Person). Tokyo: Akishobo.

Yamada, Masahiro. 2014. Kazoku nanmin (Family Refugees). Tokyo: Asahi Shinbun Shuppan.

Yoshida, Taichi. 2011. Watashi no ihin wo negaishimasu (I Ask You to Handle My Dead Belongings). Tokyo: Gentosha.

Yoshida, Taichi. 2015. Anata no fudōsanga "fudōsan"ni naru (Making Your Real Estate Responsible Property). Tokyo: Poplar Shinsho. 